\title{
Pharmacokinetic Study of Allixin, a Phytoalexin Produced by Garlic
}

\author{
Yukihiro Kodera, ${ }^{*, a}$ Makoto IchiKaWA, ${ }^{a}$ Jiro Yoshida, ${ }^{a}$ Naoki Kashimoto, ${ }^{a}$ Naoto UdA,,${ }^{a}$ \\ Isao SumioKa, ${ }^{a}$ Nagatoshi IDE, ${ }^{a}$ and Kazuhisa ONO ${ }^{b}$ \\ Healthcare Institute, Wakunaga Pharmaceutical Co., Ltd., ${ }^{a} 1624$ Shimokotachi, Koda-cho, Takatagun, Hiroshima 739 \\ 1195, Japan and Department of Molecular Biotechnology, Graduate School of Advanced Science of Matter, Hiroshima \\ University, ${ }^{b}$ 1-3-1 Kagamiyama, Higashihiroshima, Hiroshima 739-8526, Japan. \\ Received October 15, 2001; accepted December 11, 2001
}

\begin{abstract}
The pharmacokinetic behavior of allixin (3-hydroxy-5-methoxy-6-methyl-2-penthyl-4H-pyran-4-one) was investigated in an experimental animal, mice. Allixin was administered using an inclusion compound because the solubility of allixin in aqueous solution is very low. The allixin content in serum and in the organs of administered animals was analyzed by liquid chromatography (LC)-MS. Most of the administered allixin disappeared within $2 \mathrm{~h}$, and the bioavailability of allixin was estimated to be $31 \%$ by obtained area under the blood concentration-time curve $(A U C)$. The metabolites of allixin were studied using the metabolic enzyme fraction of liver and liver homogenate. Several new peaks corresponding to allixin metabolites were observed in the HPLC chromatoprofile. The chemical structure of the metabolites was investigated using LC-MS and NMR. Three of them were identified as allixin metabolites having a hydroxylated pentyl group.
\end{abstract}

Key words allixin; pharmacokinetic; metabolism; inclusion compound; phytoalexin

Intact constituents or transformation compounds derived from garlic (Allium sativum L.) have been investigated for more than 60 years, and numerous compounds have been isolated and investigated to reveal the relationship between the compounds and biological activities of garlic. ${ }^{1,2}$ Sulfur-containing compounds, such as allicin, diallylsulfides, dithiins, alliin and S-allylcysteine, have been well investigated by numerous researchers because garlic is rich in sulfur and its sulfur containing compounds were believed to be responsible for many biological activities of garlic. ${ }^{1,2)}$ S-Allylcysteine has been investigated comprehensively, including its physical, chemical and biological properties. ${ }^{1-6)}$ On the other hand, other compounds such as saponins, proteins or maillard reaction products derived from garlic, which are non-sulfur containing compounds, have also been investigated to reveal the biological properties of garlic. ${ }^{1,2,7-10)}$

Allixin (3-hydroxy-5-methoxy-6-methyl-2-penthyl-4Hpyran-4-one), a non-sulfur containing compound having a $\gamma$ pyrone skeleton structure (Fig. 1), was the first compound isolated from garlic as a phytoalexin, a product induced in plants by continuous stress. ${ }^{11)}$ This compound has been shown to have unique biological properties, such as anti-oxidative effects, ${ }^{11)}$ anti-microbial effects, ${ }^{11)}$ anti-tumor promoting effects, ${ }^{12}$ inhibition of aflatoxin $\mathrm{B}_{2}$ DNA binding, ${ }^{13)}$ and neurotrophic effects. ${ }^{14)}$ Allixin showed an anti-tumor promoting effect in vivo, inhibiting skin tumor formation by TPA in DMBA initiated mice. ${ }^{12)}$ Analogs of this compound have exhibited anti tumor promoting effects in in vitro experimental conditions. ${ }^{15)}$ Herein, allixin and/or its analogs may be expected useful compounds for cancer prevention or chemotherapy agents for other diseases.

Analysis of the biological mechanism of action of allixin is important for the study of cancer prevention or other biological properties, and also for drug development. Nishino et $a l$. has reported that allixin interacts with the $\mathrm{Ca}^{2+}$-calmodulin complex. ${ }^{12)}$ This in vitro study suggests that allixin may play an important role in signal transduction or regulation. However, the pharmacokinetic behavior of this compound has not been evaluated, and this is an important factor for in vivo studies. Therefore, this paper presents the pharmacokinetic behavior and identified metabolites of allixin.

\section{Result}

Preparation of Allixin and Allixin- $d_{11}$ Allixin and allixin- $d_{11}$ were prepared as previously reported. ${ }^{16)}$ The chemical structure of the obtained materials were confirmed by NMR and MS comparison with previous reporteds. ${ }^{11,16)}$ Synthesized allixin- $d_{11}$ was used as the internal standard for the analysis of allixin content in blood samples. The yield of allixin and allixin- $d_{11}$ was $20 \%$ and $9 \%$, respectively. Here, all
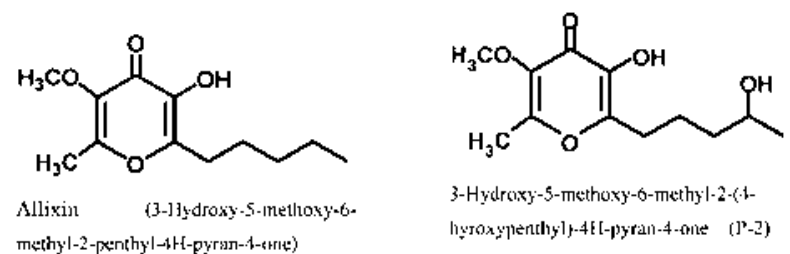

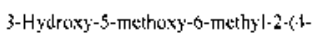

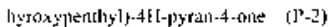

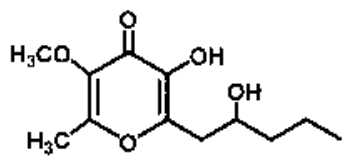

5.E[yusany-s-methory-6-methyl-2-(2-

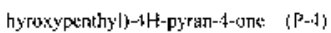

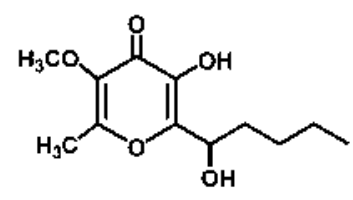

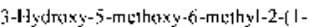

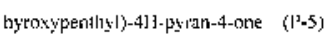<smiles>Cc1cc(=O)c(O)c(C)o1</smiles><smiles></smiles>

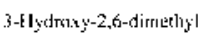

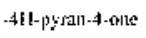

Fig. 1. Chemical Structures of Allixin and Its Analogues

Abbreviation in parenthesis is the temporarily used name for allixin metabolites in this report. 
protons in the $n$-pentyl group of allixin were replaced with deuterium on the synthesis of allixin- $d_{11}$ using 1-bromopentane- $d_{11}$. Allixin : Mass; $[\mathrm{M}+\mathrm{H}]^{+}=227,{ }^{1} \mathrm{H}-\mathrm{NMR}\left(\mathrm{CDCl}_{3}\right) \delta$ : $0.91(3 \mathrm{H}, \mathrm{t}, J=6.96), 1.34(4 \mathrm{H}, \mathrm{m}), 1.61(4 \mathrm{H}, \mathrm{m}), 2.34(3 \mathrm{H}$, $\mathrm{s},-\mathrm{Me}), 3.89$ (3H, s, $-\mathrm{OMe}), 6.1-6.35(1 \mathrm{H}, \mathrm{br},-\mathrm{OH}),{ }^{13} \mathrm{C}-$

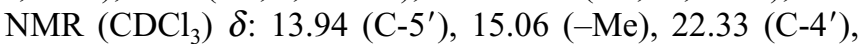
$26.39\left(\mathrm{C}-1^{\prime}\right), 28.31\left(\mathrm{C}-2^{\prime}\right), 31.26\left(\mathrm{C}-3^{\prime}\right), 60.14$ (-OMe), 141.84 (C-3, C-5), 150.15 (C-2), 158.09 (C-6), 169.48 $(\mathrm{C}=\mathrm{O})$. Allixin- $d_{11}$ : Mass; $[\mathrm{M}+\mathrm{H}]^{+}=238,{ }^{1} \mathrm{H}-\mathrm{NMR}\left(\mathrm{CDCl}_{3}\right)$ $\delta$ : $6.7-6.9(\mathrm{H},-\mathrm{OH}), 3.85\left(\mathrm{~s}, 3 \mathrm{H},-\mathrm{OCH}_{3}\right), 2.35(\mathrm{~s}, 3 \mathrm{H}$, $\left.-\mathrm{CH}_{3}\right),{ }^{13} \mathrm{C}-\mathrm{NMR}\left(\mathrm{CDCl}_{3}\right) \quad \delta: 17-18(\mathrm{~m}), 19.5(-\mathrm{Me})$, $25.2-26.2(\mathrm{~m}), 29.6-32(\mathrm{~m}), 31.6-32.4(\mathrm{~m}), 34.2-35$ (m), 60.0 (-OMe), 142 (C-3, C5), 151 (C-2), 158 (C-6), 169 $(\mathrm{C}=\mathrm{O})$.

Measurement of the Stability Constant of the Complex Compound Figure 2 showed phase solubility of allixin with maltosyl- $\beta$-cyclodextrin ( $\mathrm{M}-\beta$-Cyd). A linear relationship was observed between the concentration of allixin and M- $\beta$-Cyd from the test of solubility in water $(r=0.999)$. This result indicated that the phase solubility diagram of allixin and $\mathrm{M}-\beta$-Cyd was an AL type in water. The stability con-

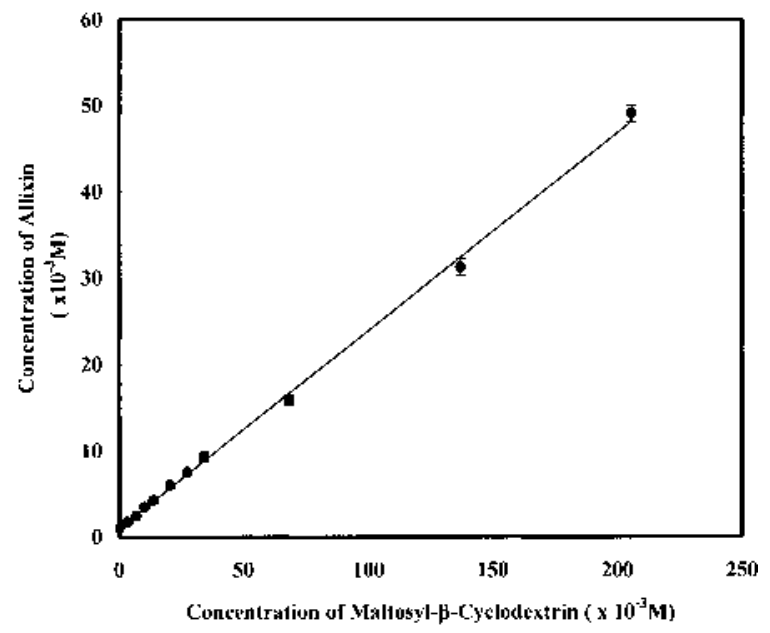

Fig. 2. Phase Solubility Diagram of Allixin with Maltosyl- $\beta$-cyclodextrin in Water

Each value represents the mean \pm S.E. of 3 samples. stant, $K\left(\mathrm{M}^{-1}\right)$, in water was 301 , according to Eq. 1 and obtained $S(=0.2291)$ and $S_{\mathrm{o}}(=0.9886 \mathrm{M}){ }^{17)}$

NMR Analysis of Inclusion Complex Compound Table 1 and Fig. 3 show the results of ${ }^{1} \mathrm{H}-\mathrm{NMR}$ measurement of intact allixin and allixin in the inclusion complex compound. Each signal relating to allixin in the inclusion compound was observed at almost the original region of the intact allixin signals. However, all of the chemical shifts of the complex corresponding to allixin migrated $0.03-0.09 \mathrm{ppm}$ down field from the signals of intact allixin. It was also observed that signals of $\mathrm{M}-\beta$-Cyd were changed on the spectrum of the complex. These observations strongly indicated that the methyl, methoxyl and pentyl group of allixin interacted with the $\mathrm{M}-\beta$-Cyd molecular structure, and that these groups might be inside the M- $\beta$-Cyd cavity (see Fig. 4).

Behavior of an Allixin Inclusion Compound in Bovine Serum Albumin (BSA) Solution and the Blood/Serum of the Experimental Animal Table 2 shows the results of allixin recovery in a mixture of allixin inclusion compound solution, and simulated serum and serum. Recovery with a filter unit was not more than $2 \%$ in each tested condition. Furthermore, no insoluble substance or crystalline substance observed in any ultrafiltrate; they remained as solution in each condition. The content of allixin in the mixture of whole blood and allixin solution was constant for each incubation time (data not shown).

Pharmacokinetic Study and Distribution of Allixin in Organs Figure 5 shows the mass chromatoprofile of selected ion monitoring and the calibration curve for allixin analysis. Allixin and internal standard allixin- $d_{11}$ were eluted at the same time. Obtained equations showed a linear line, and the range of regression coefficient was 0.986 to 0.999 .

Table 1. Chemical Shift of Allixin and Inclusion Compound

\begin{tabular}{ccccc}
\hline \hline Group in allixin & Alone (ppm) & Complex (ppm) & $\Delta \delta(\mathrm{ppm})$ \\
\hline \multirow{2}{*}{ Pentyl } & $1^{\prime}$ & 2.751 & 2.805 & 0.054 \\
& $2^{\prime}$ & 1.703 & 1.766 & 0.063 \\
& $3^{\prime}, 4^{\prime}$ & 1.332 & 1.387 & 0.055 \\
& $5^{\prime}$ & 0.885 & 0.921 & 0.036 \\
\multicolumn{2}{l}{$\begin{array}{l}\text { O-Methoxy } \\
\text { Methyl }\end{array}$} & 3.791 & 3.835 & 0.044 \\
\hline
\end{tabular}

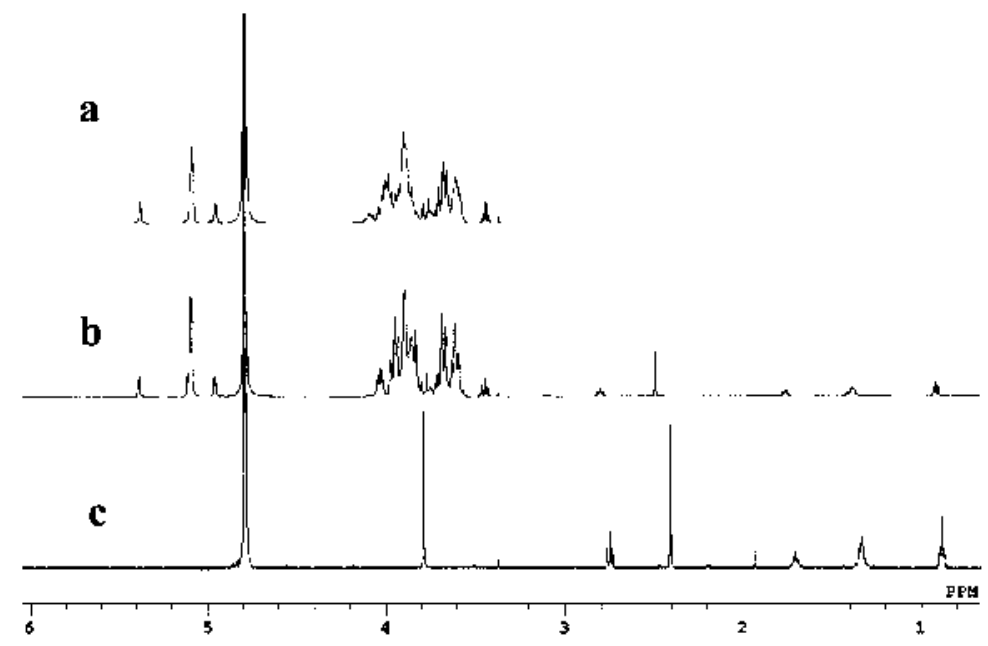

Fig. 3. ${ }^{1} \mathrm{H}-\mathrm{NMR}$ Spectrum of Allixin, Maltosyl- $\beta$-cyclodextrin and Inclusion Complex

(a) Maltosyl- $\beta$-cyclodextrin, (b) inclusion complex, (c) allixin. 
Figure 6 shows allixin concentration-time profiles in mice serum after peroral and intravenous administration, respectively. Table 3 shows pharmacokinetic parameters for allixin administration in mice. Although a decrease in spontaneous

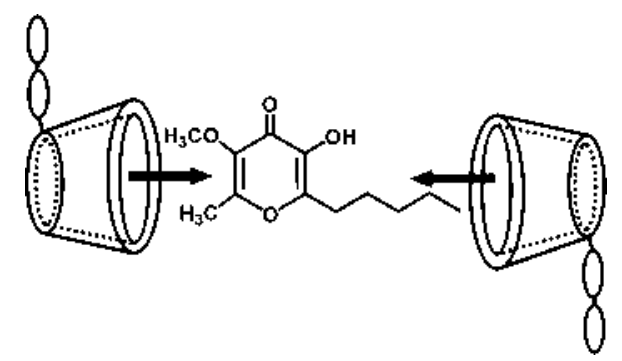

Fig. 4. Illustration of the Hypothetical Structure of an Inclusion Compound with Allixin and Maltosyl- $\beta$-cyclodextrin
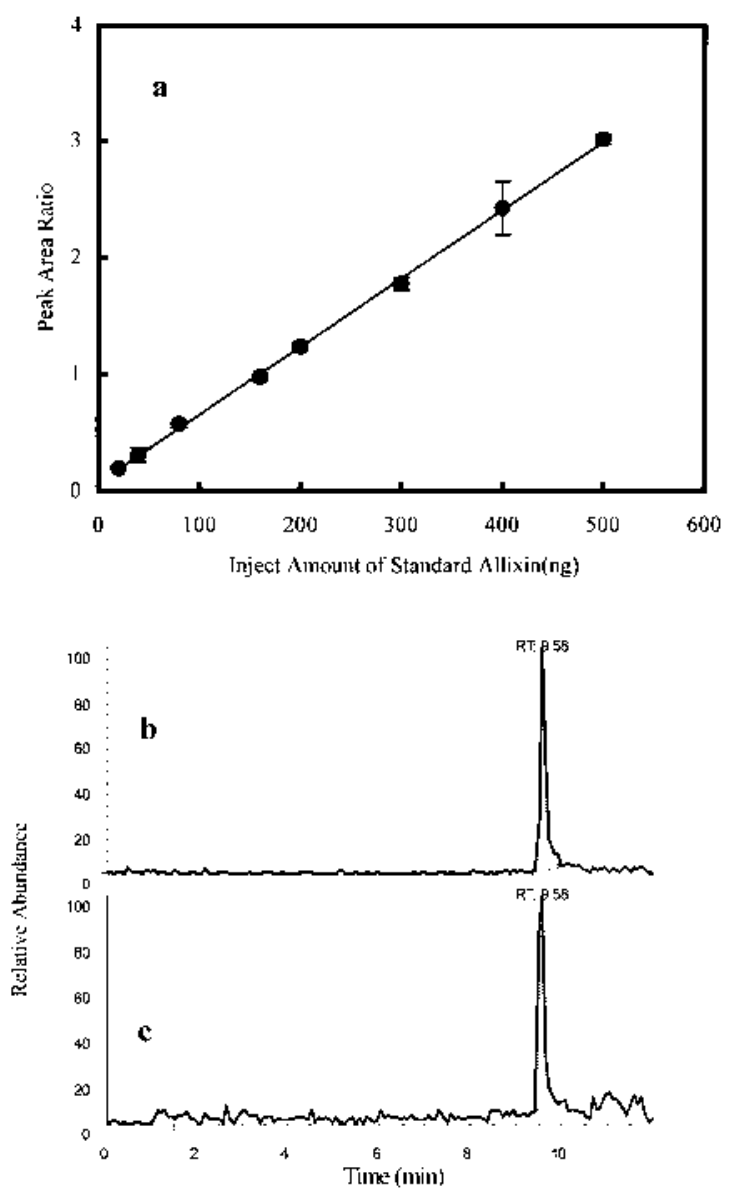

Fig. 5. Mass Chromatoprofile of Selected Ion Monitoring and Calibration Curve for Allixin Analysis

(a) Relationship between injected amount of standard allixin and peak area ratio. Obtained equation and regression coefficient on Fig. 5a was $Y=0.09267+0.005691 \cdot X, r=$ 0.9946 , respectively. (b) Chromatoprofile of standard allixin at injection of $200 \mathrm{ng}$ of allixin, (c) chromatoprofile of internal standard allixin- $d_{11}$ at injection of $200 \mathrm{ng}$ of allixin- $d_{11}$. Each value in Fig. 5a represents the mean \pm S.E. of 3 measurements. motor activities was observed in the general state observation in the intravenous administration group, but not in the peroral administration group, this sign disappeared at around $30 \mathrm{~s}$ to $1 \mathrm{~min}$ after administration. In orally administered mice, allixin concentration in the serum had already reached the maximum level $\left(C_{\max }: 2.54 \pm 1.89 \mu \mathrm{g} / \mathrm{ml}\right)$ at $5 \min \left(T_{\max }\right.$ : $5 \mathrm{~min})$ after administration, and the half-life $\left(t_{1 / 2 \beta}\right)$ of allixin was $66.5 \pm 25.7 \mathrm{~min}$. The concentration of allixin in serum quickly decreased by 10 min following intravenous adminis-

Table 2. Behavior of Allixin Inclusion Compound in BSA Solution and Serum

\begin{tabular}{|c|c|c|c|c|c|}
\hline \multirow{2}{*}{$\begin{array}{c}\text { Tested } \\
\text { material }\end{array}$} & \multirow{2}{*}{$\begin{array}{l}\text { Incubation } \\
\text { time (min) }\end{array}$} & \multicolumn{4}{|c|}{ Recovery (\%) } \\
\hline & & $\begin{array}{c}\text { Filter } \\
\text { unit }\end{array}$ & Ultrafiltrate & $\begin{array}{c}\text { Remaining } \\
\text { solution }\end{array}$ & $\begin{array}{l}\text { Corrected with } \\
\text { recovered volume }\end{array}$ \\
\hline Filter unit ${ }^{a)}$ & & 0.5 & & & \\
\hline \multirow[t]{2}{*}{ BSA solution } & 5 & 1.1 & 4.0 & 70 & 82 \\
\hline & 15 & 1.1 & 4.7 & 64 & 80 \\
\hline Filter unit $\left.{ }^{a}\right)$ & & 0.8 & & & \\
\hline \multirow[t]{2}{*}{ Serum } & 5 & 0.8 & 8.8 & 69 & 92 \\
\hline & 15 & 1.3 & 10.5 & 68 & 94 \\
\hline
\end{tabular}

a) Amount of allixin trapped by filter unit in the experiment without BSA solution or serum. b) sum of recovery, corrected with recovered volume of ultrafiltrate or remaining solution.
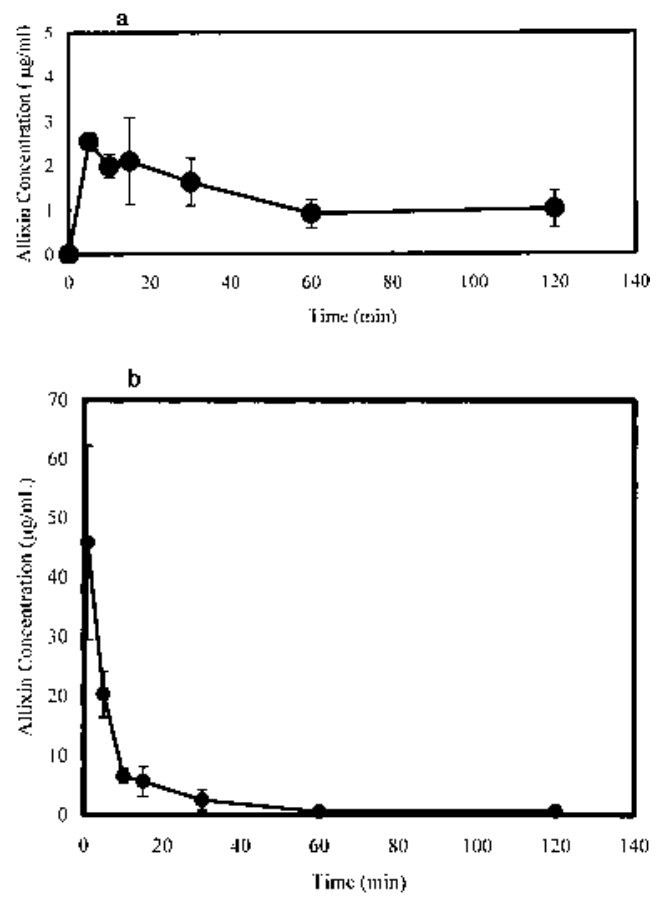

Fig. 6. Allixin a Concentration-Time Profile in Mice Serum after Peroral and Intravenous Administration at a Dose of $50 \mathrm{mg} / \mathrm{kg}$

(a) Profile of peroral administration, (b) profile of intravenous administration. Each value represents the mean \pm S.E. of 5 animals.

Table 3. Pharmacokinetic Parameters for Allixin Administration in Mice

\begin{tabular}{ccccccc}
\hline \hline Route & $T_{\max }(\min )$ & $C_{\max }(\mu \mathrm{g} / \mathrm{ml})$ & $t_{1 / 2 \beta}(\mathrm{min})$ & AUC $(\mu \mathrm{g} \min / \mathrm{ml})$ & MRT $(\mathrm{min})$ & Bioavailability $(\%)$ \\
\hline i.v. & & & $43.0 \pm 6.9$ & $375 \pm 45$ & $13.9 \pm 3.0$ & \\
p.o. & 5 & $2.54 \pm 1.89$ & $66.5 \pm 25.7$ & $117 \pm 49$ & $33.1 \pm 13.1$ & 31
\end{tabular}

Allixin was administered at a dose of $50 \mathrm{mg} / \mathrm{kg}$ using an inclusion compound in which the allixin the content in inclusion compound was $51.2 \mathrm{mg} / \mathrm{g}$. Values in the table are mean \pm S.E. $n=5$. 

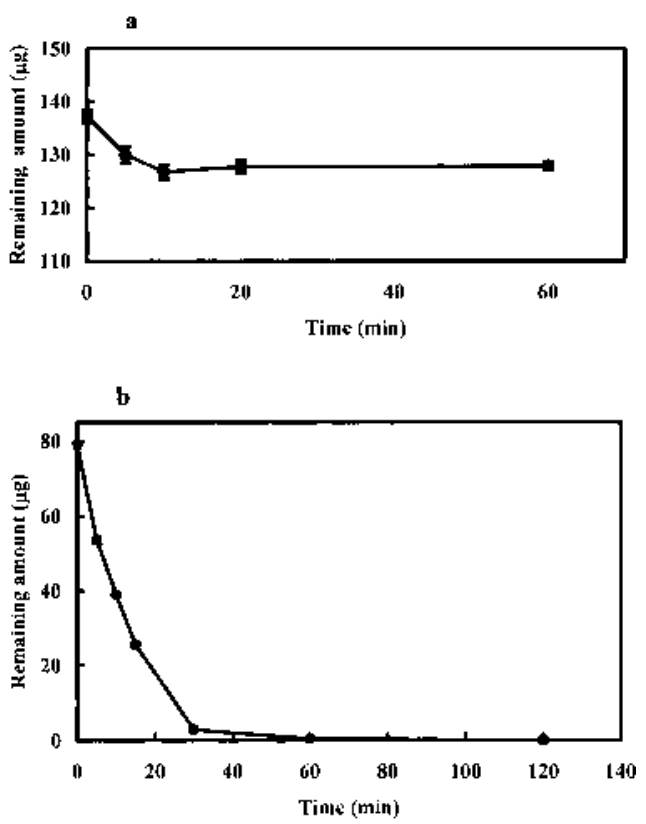

Fig. 7. Metabolism of Allixin Following Liver Homogenate and S-9 Mix Treatment

(a) Profile of treatment with liver homogenate, (b) profile of treatment with S-9 Mix Each value represents the mean \pm S.E. of 3 samples.

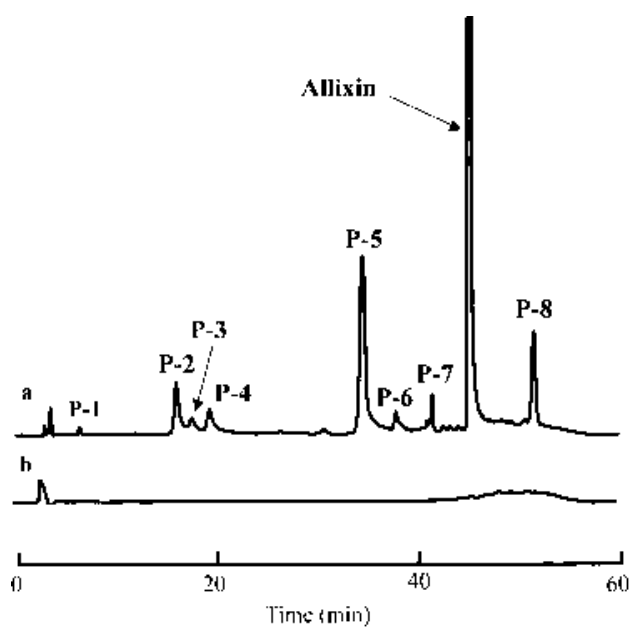

Fig. 8. Chromatoprofile of S-9 Mix Fraction and Allixin Sample Treated with S-9 Mix

(a) Chromatoprofile of allixin sample treated with S-9 mix after $3 \mathrm{~h}$ incubation, (b) chromatoprofile of S-9 Mix fraction. Five milliliters of S-9 Mix and $45 \mathrm{ml}$ of co-factor was mixed, and the resulting mixture was added to allixin suspended in PBS mixture. This mixture was incubated at $37^{\circ} \mathrm{C}$ for $3 \mathrm{~h}$.

tration, and the half-life $t_{1 / 2 \beta}$ was $43.0 \pm 6.9 \mathrm{~min}$. Table 3 shows the distribution of allixin in mice organs. The ratios of allixin distribution in the organs against serum concentration ( $\mathrm{T} / \mathrm{S}$ ratio) were investigated, and the $\mathrm{T} / \mathrm{S}$ ratio of the lung was higher than for other organs at one minute after intravenous administration. The $\mathrm{T} / \mathrm{S}$ ratio of organs related to metabolism and excretion, i.e. the liver and kidney, increased within $10 \mathrm{~min}$, then these ratios gradually decreased over time in both administrations, except in the liver with intravenous administration. The bioavailability of allixin in mice after peroral administration was estimated to be $31 \%$ using an inclusion compound with M- $\beta$-Cyd.

Treatment of Allixin with Liver Homogenate and S-9

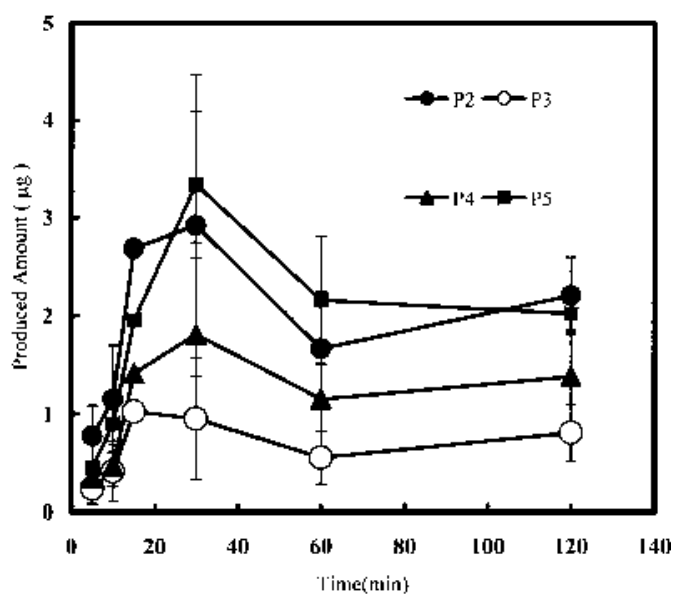

Fig. 9. Change in Produced Allixin Metabolite Amount by Incubation time

This quantitative analysis was not accurate because it is difficult to synthesize each of the allixin metabolites. Then, 3-hydroxy-2,6-dimethyl- $4 H$-pyran-4-one was used as the standard for quantitative analysis of allixin metabolites. The obtained sample solution was analyzed under the following conditions: column : TSK gel ODS 80TM (4.6 $\mathrm{mm} \phi \times 150 \mathrm{~mm})$, solvent: gradient with mixture of water and methanol $(60: 40)$ and mixture of methanol and water $(90: 10)$, detection : UV $280 \mathrm{~nm}$, flow : $0.6 \mathrm{ml} / \mathrm{min}$. Each value represents the mean \pm S.E. of 3 samples.

Mix Figure 7 shows the results of liver homogenate treatment and S-9 Mix treatment for allixin. The content of allixin in the liver homogenate mixture gradually decreased within $10 \mathrm{~min}$, and content of allixin in the reaction mixture did not change upon further incubation. The allixin content in the reaction mixture decreased over time, and all the allixin disappeared within 60 min upon treatment with the S-9 Mix. Figure 8 shows the HPLC chromatoprofile of the S-9 Mix treatment sample. Several new peaks that were absent in the enzyme fraction S-9 Mix were observed in the S-9 Mix treatment sample. Newly observed peaks in the HPLC profile were named P-1 to P-8, respectively. Figure 9 shows changes in the amount of metabolites produced during the incubation time. The peaks, named P-2 and P-5, were observed as the main metabolite under the analytical conditions performed.

Identification of Metabolites of Allixin The fractions corresponding to these new peaks were recovered by HPLC, and structure analysis was performed using MS and NMR equipment. Figure 10 shows the mass spectra of allixin and the allixin metabolite corresponding to P-5. The peak corresponding to P-2 to P-5 gave protonated molecular ions and fragment ion, $[\mathrm{M}+\mathrm{H}]^{+}=243$ and $[\mathrm{M}+\mathrm{H}-16]^{+}=225$, respectively, on liquid chromatography (LC)-MS analysis for each isolated fraction. $m / z=255$ was also observed on the MS/MS function mode of MS analysis. This indicates the addition of oxygen to allixin, since the ion of 243 is 16 mass different from the ion of allixin $\left([\mathrm{M}+\mathrm{H}]^{+}=227\right)$, and the ion of 225 indicates the ion of $\left[\mathrm{M}+\mathrm{H}-\mathrm{H}_{2} \mathrm{O}\right]^{+}=[242+1-18]^{+}$. The signal corresponding to the $\mathrm{C}-4^{\prime}$ bonded proton of allixin was not observed on the obtained NMR spectrum of P2 , but a new signal was observed at $3.842 \mathrm{ppm}$. Cross peak signals of protons corresponding to position C-3' (1.724 $\mathrm{ppm}) / \mathrm{C}-4^{\prime}$ (3.842 ppm) and position C-4' (3.842 ppm)/C-5' $(1.155 \mathrm{ppm})$ were observed on ${ }^{1} \mathrm{H}-{ }^{1} \mathrm{H}$ correlation spectroscopy (COSY) analysis of P-2. These results from P-2 indicate that the $\mathrm{C}-4^{\prime}$ position on the pentyl group of allixin would have a hydroxyl group due to an oxidative reaction. 

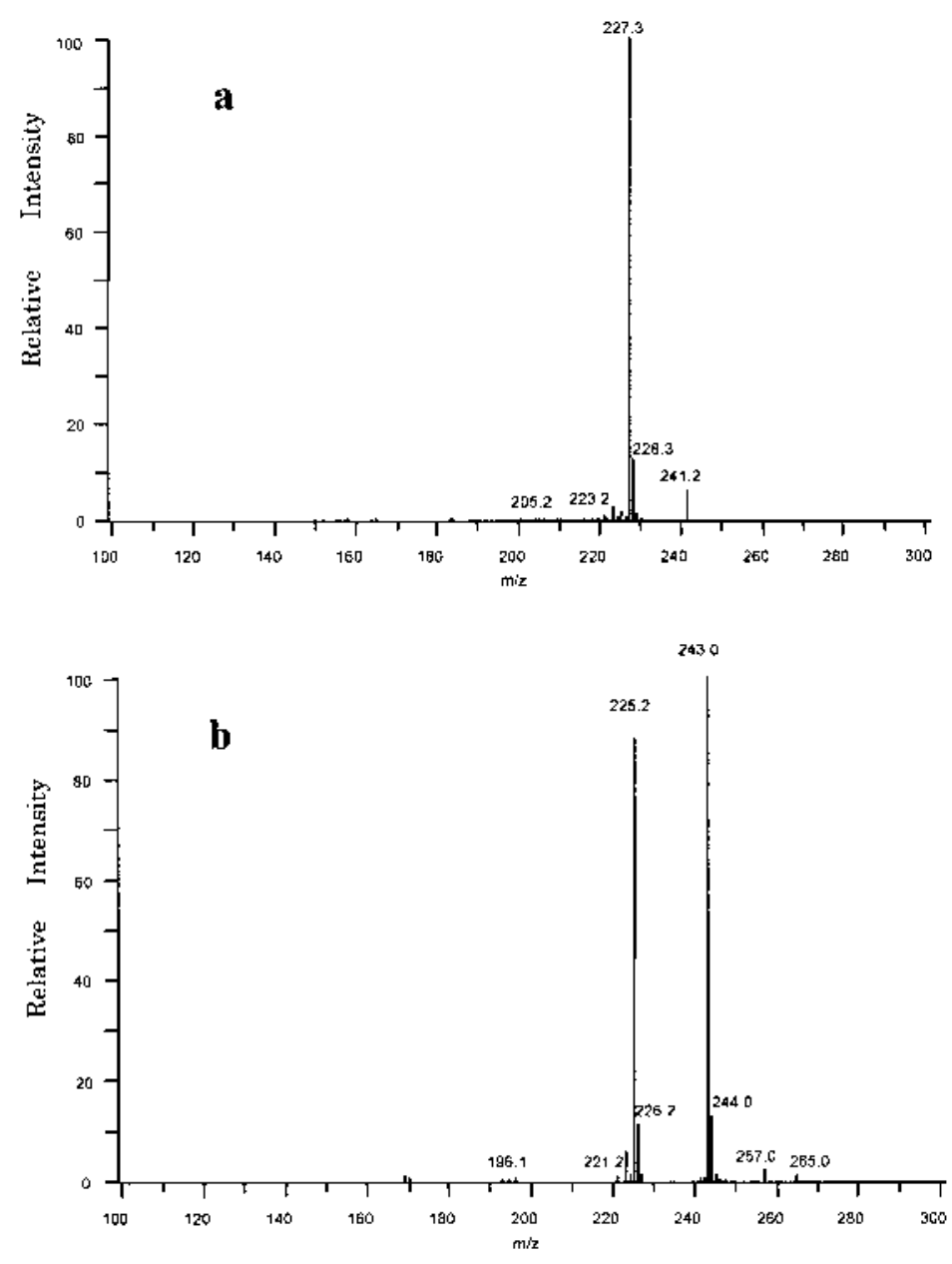

Fig. 10. Mass Spectra of Allixin and Allixin Metabolite P-5

(a) Allixin, (b) allixin metabolite corresponding to P-5 on Fig. 8.

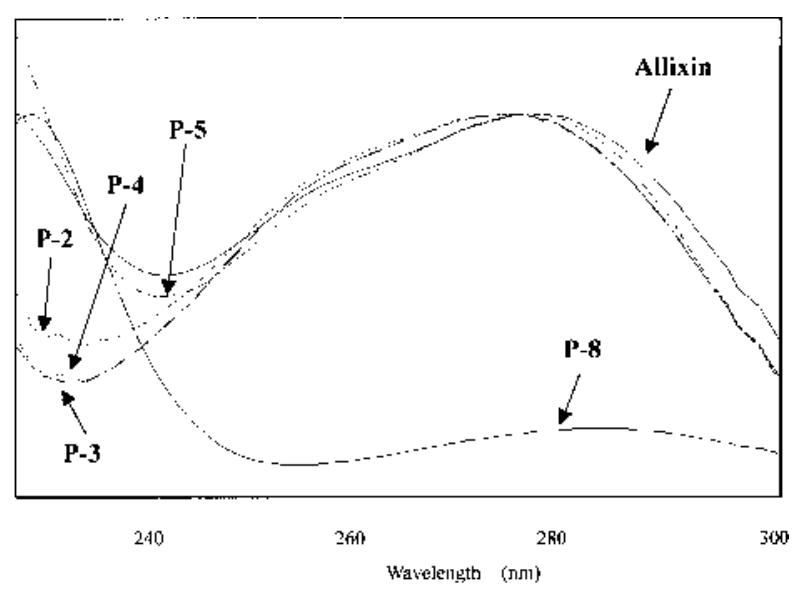

Fig. 11. UV Spectra of Allixin and Its Metabolite

Name of each curve corresponding to the name of each peak in Fig. 8.

UV spectra of P-2 to P-5 were similar to allixin, but the maximum absorption was slightly shifted to the short wavelength side (Fig. 11). These metabolites would be analogue of allixin. The UV spectrum of P-8 differed from allixin and the peaks of P-2 to P-5, and the peak corresponding to P-8 was not observed in the HPLC chromatoprofile of the liver sample upon intravenous administration (Fig. 12). Furthermore, other new peaks corresponding to P-1, P-6 and p-7 in the

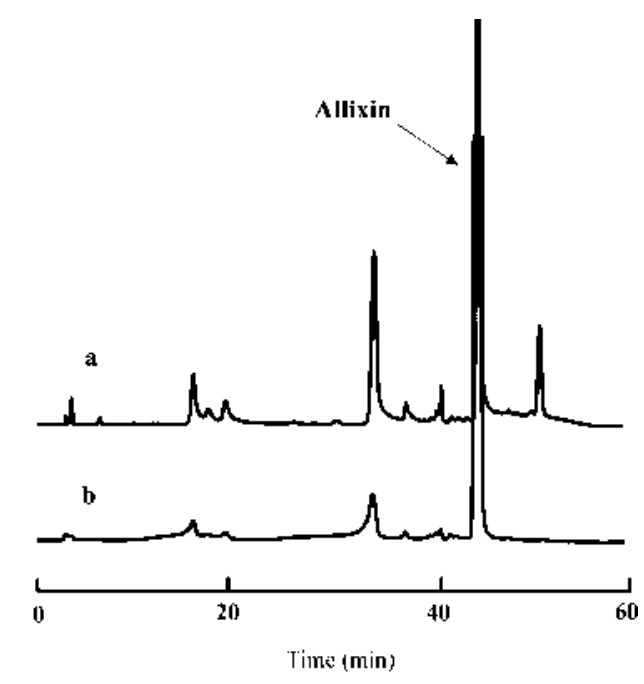

Fig. 12. Chromatoprofile of S-9 Mix-Treated Allixin Fraction and Liver Sample on Intravenous Administration

(a) S-9 Mix-treated allixin fraction, (b) sample at 10 min after administration.

chromatoprofile on Figs. 8 and 12 demonstrate a different UV spectrum from P-2 to P-5 and P-8; for example, no absorption around $280 \mathrm{~nm}$, or $\mathrm{UV}_{\max }$ absorption at $225 \mathrm{~nm}$ or $240 \mathrm{~nm}$ (detailed data not shown). Therefore, a detailed investigation of the structural analysis of P-1, P-6, P-7 and P-8 
Table 4. Distribution of Allixin in Mice Organs

Allixin content $(\mu \mathrm{g} / \mathrm{g} \text {-wet organ })^{a}$

\begin{tabular}{|c|c|c|c|c|c|c|c|c|}
\hline \multirow[t]{2}{*}{ Route } & \multirow[t]{2}{*}{ Organ } & \multicolumn{7}{|c|}{ Time (min) } \\
\hline & & 1 & 5 & 10 & 15 & 30 & 60 & 120 \\
\hline \multirow[t]{5}{*}{ i.v. } & Brain & $79.92 \pm 52.32$ & $18.43 \pm 5.31$ & $3.87 \pm 0.73$ & $5.21 \pm 0.72$ & $2.73 \pm 1.41$ & $0.92 \pm 0.73$ & $0.52 \pm 0.56$ \\
\hline & Lung & $160.19 \pm 171.81$ & $27.26 \pm 18.16$ & $10.62 \pm 4.87$ & $29.38 \pm 11.55$ & $8.27 \pm 3.06$ & $7.51 \pm 4.80$ & $5.53 \pm 3.76$ \\
\hline & Kidney & $33.35 \pm 21.08$ & $39.56 \pm 7.18$ & $22.03 \pm 8.76$ & $18.02 \pm 6.47$ & $13.63 \pm 10.59$ & $1.87 \pm 0.75$ & $1.63 \pm 0.90$ \\
\hline & Liver & $15.70 \pm 20.51$ & $52.92 \pm 28.36$ & $33.69 \pm 9.56$ & $44.07 \pm 14.91$ & $24.55 \pm 6.99$ & $8.46 \pm 3.62$ & $14.56 \pm 12.77$ \\
\hline & Serum & $45.89 \pm 14.64$ & $20.37 \pm 3.48$ & $6.57 \pm 1.11$ & $5.64 \pm 2.21$ & $2.51 \pm 1.55$ & $0.61 \pm 0.06$ & $0.68 \pm 0.21$ \\
\hline \multirow[t]{5}{*}{ p.o. } & Brain & & $1.13 \pm 2.09$ & $0.07 \pm 0.11$ & $0.06 \pm 0.09$ & Trace & $0.25 \pm 0.25$ & $0.28 \pm 0.07$ \\
\hline & Lung & & $0.87 \pm 1.95$ & Trace & $2.39 \pm 5.33$ & Trace & $5.30 \pm 1.34$ & $6.93 \pm 2.56$ \\
\hline & Kidney & & $4.18 \pm 3.96$ & $5.81 \pm 4.02$ & $3.08 \pm 2.77$ & $9.90 \pm 6.52$ & $4.59 \pm 3.44$ & $4.72 \pm 2.58$ \\
\hline & Liver & & $40.65 \pm 5.14$ & $21.61 \pm 6.26$ & $20.07 \pm 8.33$ & $19.18 \pm 7.43$ & $9.05 \pm 7.75$ & $8.75 \pm 2.67$ \\
\hline & Serum & & $2.54 \pm 0.16$ & $1.98 \pm 0.24$ & $2.09 \pm 0.98$ & $1.30 \pm 0.76$ & $0.91 \pm 0.29$ & $1.01 \pm 0.37$ \\
\hline
\end{tabular}

a) Mean \pm S.E., $b) n=5$.

was not performed.

Analytical results of P-2, P-3, P-4 and P-5 on NMR and MS analysis are shown as follow, respectively.

Results of P-2: Atmospheric pressure chemical ionization (APCI)-LC-MS $m / z: 243,[\mathrm{MS} / \mathrm{MS}]=225,{ }^{1} \mathrm{H}-\mathrm{NMR}\left(\mathrm{D}_{2} \mathrm{O}\right)$ $\delta: 1.155(\mathrm{~d}, 3 \mathrm{H}, 6 \mathrm{~Hz}), 1.483(\mathrm{~m}, 2 \mathrm{H}), 1.724(\mathrm{~m}, 2 \mathrm{H}), 2.374$ (s, 3H), 2.747 (m, 2H), 3.764 (s, 3H), $3.842(\mathrm{~m}, \mathrm{H}),{ }^{1} \mathrm{H}-{ }^{1} \mathrm{H}$ COSY cross peak: 1.155 and 3.482, 1.483 and 3.482, 1.483 and $1.724,1.724$ and 2.747

Result of P-3: APCI-LC-MS $m / z$ : 243, $[\mathrm{MS} / \mathrm{MS}]=225$, ${ }^{1} \mathrm{H}-\mathrm{NMR}\left(\mathrm{D}_{2} \mathrm{O}\right) \delta$ : Assured results for the assignment of ${ }^{1} \mathrm{H}-$ NMR signals were not obtained.

Results of P-4: APCI-LC-MS $m / z$ : 243, [MS/MS] $=225$, ${ }^{1} \mathrm{H}-\mathrm{NMR}\left(\mathrm{D}_{2} \mathrm{O}\right) \delta: 0.914(\mathrm{t}, 3 \mathrm{H}, 7 \mathrm{~Hz}), 1.484(\mathrm{~m}, \mathrm{H}), 1.553$ $(\mathrm{m}, \mathrm{H}), 1.786(\mathrm{~m}, \mathrm{H}), 1.925(\mathrm{~m}, \mathrm{H}), 2.402(\mathrm{~s}, 3 \mathrm{H}), 2.822(\mathrm{~m}$, 2H), $3.604(\mathrm{~m}, \mathrm{H}), 3.783(\mathrm{~s}, 3 \mathrm{H}){ }^{1} \mathrm{H}-{ }^{1} \mathrm{H}$ COSY cross peak: and 1.484 and $1.553,1.484$ and 1.553 and 3.604, 1.786 and 1.925 and 2.822

Results of P-5: APCI-LC-MS $m / z$ : 243, [MS/MS] $=225$, ${ }^{1} \mathrm{H}-\mathrm{NMR}\left(\mathrm{D}_{2} \mathrm{O}\right) \delta: 0.865(\mathrm{t}, 3 \mathrm{H}, 7.4 \mathrm{~Hz}), 1.331(\mathrm{~m}, 4 \mathrm{H})$, $1.850(\mathrm{~m}, 2 \mathrm{H}), 2.419(\mathrm{~s}, 3 \mathrm{H}), 3.787(\mathrm{~s}, 3 \mathrm{H}), 5.033(\mathrm{t}, \mathrm{H}, 7.4$ $\mathrm{Hz}),{ }^{1} \mathrm{H}-{ }^{1} \mathrm{H}$ COSY cross peak: 0.865 and $1.331,1.850$ and $5.033,1.331$ and 1.850

These results suggest that new peaks were observed as metabolites of allixin; P-2, P-4 and P-5 were 3-hydroxy-5methoxy-6-methyl-2-(4-hyroxypentyl)-4H-pyran-4-one, 3-hydroxy-5-methoxy-6-methyl-2-(2-hyroxypentyl)-4H-pyran-4one and 3-hydroxy-5-methoxy-6-methyl-2-(1-hyroxy-pentyl)$4 H$-pyran-4-one, respectively.

\section{Discussion}

Allixin, a non-sulfur containing compound with a $\gamma$-pyrone skeleton structure, was the first phytoalexin, induced in a plant by continuous stress, isolated from garlic, ${ }^{11,18,19)}$ and this compound has shown unique biological properties. ${ }^{1-15)}$ There was no previous study relating to the pharmacokinetics of allixin, though several biological properties of allixin were investigated in both in vitro and in vivo systems as described above. Therefore, we investigated the pharmacokinetic behavior of allixin because it is well known that pharmacokinetic behaviors, parameters and metabolites of drugs are important factors for studying the action mechanisms and /or development of new drugs.
Allixin is slightly soluble in water ( $c a .200 \mu \mathrm{g} / \mathrm{ml}>$ ); the calculated $\log P$ of allixin is $3.89 \pm 0.75$. The solubilization of new drugs with poor aqueous solubility is crucial for pharmacological evaluation. The use of biologically incompatible organic solvents or surfactants in testing is undesirable for a living body. Cyclodextrins form inclusion complexes with hydrophobic compounds, and the resulting complex improves the solubility of these hydrophobic compounds in aqueous solution. ${ }^{1720-22)}$ Recently, several cyclodextrin derivatives have been developed to improve solubility in aqueous solution. The practical use of natural cyclodextrin as a drug carrier, however, is restricted by its low aqueous solubility. Maltosyl- $\beta$-cyclodextrin (M- $\beta$-Cyd) is a $\beta$-cyclodextrin derivative that improves solubility, and this material improved the solubility of allixin in aqueous solution (Fig. 2).

The results of ${ }^{1} \mathrm{H}-\mathrm{NMR}$ measurement of an intact substance and the inclusion complex shows an obvious interaction between allixin and M- $\beta$-Cyd. All of the chemical shifts of the complex corresponding to allixin migrated $0.03-0.09$ ppm downfield from signals of intact allixin, though the migration of $\mathrm{M}-\beta$-Cyd signals were not distinguished clearly. Observations of allixin signals in the inclusion compound indicated that methyl, methoxyl and pentyl groups of allixin interacted with the M- $\beta$-Cyd molecule. ${ }^{23,24)}$ It is said that the diameter of the cyclodextrin cavity is $7-8 \AA .^{25)}$ The distance of carbon atoms between $O$-methoxide in position five and methyl in position six was calculated to be $3.295 \AA$ (calculated by PM3 Hamiltonian in MOPAC97, WinMOPAC ver2.0, Fujitsu, Japan), and the distance between carbon and hydrogen is $1.1 \AA$. Therefore, the cavity of M- $\beta$-Cyd is large enough to include the spatial area of both of $O$-methoxide and methyl groups, and these groups would be inside of $\mathrm{M}$ $\beta$-Cyd cavity, as shown in Fig. 4. However, the phase solubility diagram indicated the equilibrium relationship to be one molecule of allixin to 4 molecules of M- $\beta$-Cyd in water. On the other hand, the inclusion complex required $1 \mathrm{~m}$ allixin to $2 \mathrm{M}$ of M- $\beta$-Cyd, though a small amount of allixin remained in the mixture as insoluble material. In the case of $1 \mathrm{~m}$ allixin to $3 \mathrm{M}$ of $\mathrm{M}-\beta$-Cyd, allixin was completely soluble. It might be considered that interactions between allixin and M- $\beta$-Cyd in aqueous solution are not strong because the solubility constant $K$ was not high $\left(K=301 \mathrm{~m}^{-1}\right)$. Indeed, a slight crystalline substance was observed in the administration solution 
several hours after preparing this inclusion compound solution at a concentration of $2 \mathrm{~g} / 10 \mathrm{ml}$. Therefore, the administration was performed within $2 \mathrm{~h}$ after preparing the administration solution. Further investigation is necessary to reveal the detailed interaction between allixin and M- $\beta$-Cyd in aqueous solution.

It is said that the compound included by the host compound is quickly released in the body from the host compound, such as M- $\beta$-Cyd, when the inclusion compound is administered. It might be that the compound released from the host compound would crystallize inside the body with high dosage administration, thus this phenomenon is a serious problem in this pharmacokinetic study. Crystallized allixin was not trapped by a membrane filter in the experiment of the interaction with BSA and rat serum (Table 2). Furthermore, no crystalline or insoluble substance was observed in either the ultrafiltrate or remaining solution. Therefore, these results indicated that allixin released from the host compound would be circulated with the carrier protein without crystalline formation.

It appears that allixin was quickly absorbed, based on the observation of a maximum level $\left(C_{\max }\right)$ at $5 \mathrm{~min}\left(T_{\max }\right)$ on peroral administration. The bioavailability of allixin in mice after peroral administration was estimated to be $31 \%$ using an inclusion compound with M- $\beta$-Cyd. The bioavailability of allixin itself in mice was low, but combining allixin with the administration substance improved its solubility in aqueous solution when the inclusion compound was prepared with M$\beta$-Cyd. However, the bioavailability of allixin was about two times higher than that of alliin $(16.5 \%),{ }^{26)}$ which is a wellknown sulfur-containing compound in intact garlic. In the preliminary administration study using an inclusion compound, allixin was not detected in rat plasma at a dose of 0.5 , 5 or $10 \mathrm{mg} / \mathrm{kg}$ upon peroral administration, while allixin was detected in intravenous administration, even at dose of 0.5 $\mathrm{mg} / \mathrm{kg}$ (data not shown, intact allixin in saline solution was used at a dose of $0.5 \mathrm{mg} / \mathrm{kg}$ ). Most of the allixin in rat plasma disappeared within two hours upon intravenous administration, as it did in mice, and the bioavailability of allixin in rat was $1.1 \%$ based on the hypothetical estimation $\left(C_{\max }=6.93\right.$ $\mu \mathrm{g} / \mathrm{ml}, T_{\max }=10 \mathrm{~min}$, at $10 \mathrm{mg} / \mathrm{kg}$-dose). The time allixin disappeared from blood in mice was almost the same as S-allylcysteine, which indicates high bioavailability, but was significantly different from that in rat. ${ }^{3)}$ Therefore, these results suggest that allixin might be experience a first-pass effect in both animals, but the details are not yet clear.

The $\mathrm{T} / \mathrm{S}$ ratio of the lung was higher than for other organs at one minute after intravenous administration. The extremely high content of allixin found in the lung compared to that in the serum and other organs during the early period after intravenous administration might be due to delivery through blood circulation and to the lipophilic property of allixin, because venous blood is carried first to the lung and then to other organs. Additionally, the calculated $\log P$ of allixin, $3.89 \pm 0.75$, indicated high lipophilicity. The content and $\mathrm{T} / \mathrm{S}$ ratio in the lung remained a little bit higher than that in the serum or some of the organs after both intravenous and peroral administration. Therefore, allixin might have some affinity for the lung. Its lipophilic property might be related to the high content of allixin found in the brain versus the serum upon intravenous administration. The $\mathrm{T} / \mathrm{S}$ ratio of those organs involved in metabolism and excretion, i.e. the liver and kidney, increased up to $10 \mathrm{~min}$, then these ratios gradually decreased over time upon both peroral and intravenous administration, except for intravenous administration in the liver. It is guessed that the administered allixin was quickly distributed to liver tissue, then this allixin in the liver would return only a small amount to the blood; thus, allixin remained and accumulated in the liver, and the $k_{12}$ (transfer rate constant from blood to liver tissue) would be larger than $k_{21}$ (transfer rate constant from liver tissue to blood) in allixin distribution in liver. The T/S ratio of liver in intravenous administration was extremely elevated compared to other organs, though the allixin absorbed was metabolized and/or excreted, and its concentration in serum was decreased by excretion. On the other hand, allixin was quickly absorbed in peroral administration, but not higher than with intravenous administration, and the allixin concentration in serum quickly reached the $C_{\max }$ level. The allixin concentration in serum in peroral administration was much lower than intravenous administration until $15 \mathrm{~min}$ after administration. Therefore, the amount of allixin distributed to the liver was lower than in the case of intravenous administration. Allixin in the liver appears to be metabolized and excreted without accumulation. The $\mathrm{T} / \mathrm{S}$ ratio of the kidney was similar with both peroral and intravenous administration, i.e., the ratio gradually increased until $30 \mathrm{~min}$ and then gradually decreased. The tested organs, except the brain, retained allixin at a higher rate than serum levels, even $120 \mathrm{~min}$ after administration. It is considered that allixin has some affinity without specificity to tissue. The reabsorption of allixin by the kidney would be expected, but this was not investigated.

The metabolism and metabolites of allixin were investigated using rat liver homogenate and a metabolic enzyme fraction derived form rat liver microsome fraction (named S9 Mix). Obviously, allixin was metabolized by these treatments (Fig. 8). Metabolites of allixin were isolated by HPLC, and the chemical structure of the isolated metabolites was investigated using NMR and LC-MS. Some of the allixin signals derived from the alkyl group on NMR analysis disappeared and new signals were observed at each isolated metabolite, respectively. Peaks corresponding to metabolites were also observed in chromatoprofile on HPLC analysis of liver samples folowing intravenous administration (Fig. 12). Based on the analytical data of metabolites, such as the shift of the UV spectrum to short wavelength, the detection of $m / z=243$ ion and $m / z=225$ ion, and the detection of cross peaks on ${ }^{1} \mathrm{H}-{ }^{1} \mathrm{H}$ COSY NMR, allixin is likely metabolized to oxidative substances by an oxidation enzyme such as P-450 after administration. Especially, an alkyl group on the side chain would be easily oxidized. Some $\gamma$-pyrone compounds, such as maltol derivatives, were investigated for use as iron chelators for patients with hemoglobinopathic disorders. ${ }^{27-32)}$ Hydroxylation of the alkyl group on the side chain of administered maltol derivatives was observed and determined to be a phase I metabolite in experimental animals and humans after oral and intravenous administration. These resulting phase I metabolites were then transformed into phase II metabolites, such as glucuroide conjugate. ${ }^{28,31)}$ Additionally, the hydroxylation of an alkyl group on the side chain was observed in the pharmacokinetic study of naturally volatile compounds, such as thymol and carvacrol. ${ }^{33)}$ Considering the 
results of these reports and our obtained results, it is strongly suggested that some position in the pentyl group would undergo hydroxylation as a metabolic reaction of phase I. Identified metabolites of allixin were produced quickly, but not major metabolites, while accurate quantitative analysis of the observed metabolites was not performed. The total amount of P-2 to P-5 at 60 min incubation with S-9 Mix was less than $10 \%$ against initial allixin content in the hypothetical estimation. It is suggested that allixin might be metabolized to another kind of compound or transformed to phase II metabolites, such as glucuroide or sulfuric acid conjugates, in a living body. The biological activity and safety of hydroxylated allixin metabolites was not evaluated because the amount isolated was small and no sufficient method of chemical synthesis was established. Hydroxylation occurs as a detoxification step (phase I metabolism) in the liver, and some metabolite produced is excreted without transformation, and/or is transformed to a phase II metabolite, such as glucuroide or sulfuric acid conjugates. ${ }^{28,31,33)}$ Allixin might be transformed to hydroxylated metabolites with this mechanism of metabolism. Thus, the toxicity of allixin metabolites would be weaker than that of intact allixin. The pharmacokinetic behavior of allixin shows very little accumulation of this compound in organs.

Allixin has been reported to have various unique biological properties in both in vitro and in vivo assay systems. Namely, this compound showed strong antitumor promoting activity in the in vivo system, i.e., in skin tumor formation promoted by TPA in DMBA initiated mice. ${ }^{12)}$ Also, the results of neurotrophic activity in the in vitro assay indicates that allixin may be beneficial in the treatment of aging problems. ${ }^{14)}$ However, it was revealed that intact allixin is not suitable for usage in oral and intravenous administration systems targeted at internal organs. An alternative investigation, such as the modification/derivative of allixin, external application and biological evaluation of allixin metabolites, would be necessary to take advantage of this potent, beneficial compound.

\section{Materials and Methods}

Chemicals and Animals Allixin administered to experimental animals and allixin- $d_{11}$ as an internal standard, were synthesized according to the previously reported method. ${ }^{16)} \mathrm{M}-\beta$-Cyd, for the preparation of an inclusion compound, was purchased from Ensuikou-Seitou (Yokohama, Japan). Previously prepared 3-hydroxy-2,6-dimethyl-4H-pyran-4-one was used as the standard for the analysis of allixin metabolites. ${ }^{14)}$ All chemicals for analysis and synthesis, except for 1-bromopentan- $d_{11}$ ( 99 atom\% deuterium, CDN Isotope, Quebec, Canada), were purchased from Wako Pure Chemicals Industries (Osaka, Japan). S-9/co-factor A set for the Ames test, named S-9 Mix, (Oriental Yeast Co., Ltd., Tokyo, Japan) was used for the investigation of allixin metabolites as a metabolism enzyme fraction. For experimental animals, 6-week old male $d d y$ mice and 14-week old wister male rats were used for this pharmacokinetic study.

Equipment The LC-MS analysis was performed using an LC-MS system composed of the Hewlett Packard HPLC ceris 1100 (Hewlett Packard, U.S.A.) and MS system of Finnigan LCQ (Finnigan Corporation, U.S.A.). The NMR spectra was taken on a JNM EX-500 spectrometer (JEOL, Tokyo, Japan). The LC-10A system (Shimadzu, Japan) was used for the quantitative analysis of allixin and its metabolites. Absorption at UV $280 \mathrm{~nm}$ was used for the quantitative and/or identical analysis of allixin and its metabolites on HPLC analysis because allixin has a maximum absorption at $280 \mathrm{~nm}$ of the ultraviolet region. ${ }^{11)}$

Preparation of an Inclusion Compound of Allixin with $\mathrm{M}-\boldsymbol{\beta}-\mathrm{Cyd}$ and Analysis of Allixin Content in This Inclusion Compound Allixin, in the amount of $300 \mathrm{mg}\left(1.33 \times 10^{-3} \mathrm{~mol}\right)$, was placed on an agate mortar, and 2 $\mathrm{ml}$ of $1 \mathrm{~N} \mathrm{NaOH}$ was added. To this was added $5.8 \mathrm{~g}$ of $\mathrm{M}-\beta$-Cyd $(3.98 \times$
$10^{-3} \mathrm{~mol}$ ) and $1 \mathrm{ml}$ of water, then this mixture was mixed well for $30 \mathrm{~min}$ by agate pestle until it became a translucent paste. A few milliliters of water was added to this mixture, and it was then adjusted to $\mathrm{pH} 7.5$ using diluted $\mathrm{HCl}$ solution. About $30 \mathrm{ml}$ of water was then added to this neutralized solution. The resulting solution was kept for $1 \mathrm{~h}$ at room temperature, then filtered by a membrane filter (pour size: $0.45 \mu \mathrm{m}$ ). The above preparation processes were repeated two more times. These filtrates were combined then the resulting translucent solution was lyophilized. The obtained lyophilized substance was pulverized into a fine powder. About $50 \mathrm{mg}$ of dry fine powered inclusion compound was weighed accurately and was placed into a 50 $\mathrm{ml}$ volumetric flask; $5 \mathrm{ml}$ of water was added for dissolution, then methanol was added to make the $50 \mathrm{ml}$ volume. Two milliliters of this solution was pipetted into a $20 \mathrm{ml}$ volumetric flask and methanol was added to fill it. The resulting solution was analyzed by the following HPLC conditions to determine allixin content in the inclusion compound. HPLC systems : LC-10A systems (Shimadzu, Kyoto, Japan), detection: UV $280 \mathrm{~nm}$ absorption, solvent: mixture of methanol and $0.1 \%$ phosphate solution $(72: 28)$, solvent flow: $0.8 \mathrm{ml} / \mathrm{min}$, column: TSK gel ODS $80 \mathrm{TM}(4.6 \mathrm{~mm} \phi \times 150 \mathrm{~mm})$ (Tosoh, Tokyo, Japan). The yield of the inclusion compound was $15.63 \mathrm{~g}$ and the content of allixin in the inclusion compound was $51.9 \mathrm{mg} / \mathrm{g}$.

NMR Analysis of the Inclusion Compound About $30 \mathrm{mg}$ of the allixin-inclusion compound and about $25 \mathrm{mg}$ of $\mathrm{M}$ - $\beta$-Cyd were each dissolved in about $1 \mathrm{ml}$ of $\mathrm{D}_{2} \mathrm{O}$, respectively. Each solution was filtered with a membrane filter (pore size: $0.45 \mu \mathrm{m}$ ), then the obtained filtrates were used for NMR analysis. One milliliter of $\mathrm{D}_{2} \mathrm{O}$ was added to a few milligrams of allixin, and this mixture was sonicated for $20 \mathrm{~min}$ to dissolve allixin. This mixture was filtered with a membrane filter (pore size: $0.45 \mu \mathrm{m}$ ), and then the obtained filtrates were measured by ${ }^{1} \mathrm{H}-\mathrm{NMR}$.

Measurement of the Stability Constant of a Complex of Allixin and M- $\boldsymbol{\beta}$-Cyd in Water Measurement of the stability constant of a complex of allixin and $\mathrm{M}-\beta$-Cyd in water was performed according to the Solubility Method. ${ }^{17)}$ Four milliliters of $0 \%$ to $30 \%$ of M- $\beta$-Cyd aqueous solution was pipetted into $10 \mathrm{ml}$ glass vials with screw caps, respectively. An appropriate amount of allixin to $\mathrm{M}$ - $\beta$-Cyd content was added to each vial. The vials containing of resulting mixture were shaken constantly at $25^{\circ} \mathrm{C}$ for $7 \mathrm{~d}(200$ strokes/min). These storage mixtures were filtered with a membrane filter (pore size: $0.45 \mu \mathrm{m}$ ) after $7 \mathrm{~d}$. One milliliter of filtrate was diluted to an appropriate concentration of allixin with methanol. The absorbency of the resulting solutions was measured to determine the allixin content which interacted with M- $\beta$-Cyd using a UV-Visible Spectrophotometer UV-1600 (Shimadzu, Kyoto, Japan) at a wavelength of $280 \mathrm{~nm}$. The solubility diagram was prepared by plotting the relationship between the mole concentration of allixin and $\mathrm{M}-\beta$-Cyd in the filtrate of each vial. The stability constant of the complex compound between allixin and maltosyl- $\beta$-cyclodextrin, $K\left(\mathrm{M}^{-1}\right)$, in water, was calculated by the following Eq. $1 .{ }^{17)}$

$$
K=S / S_{\mathrm{o}}(1-S)
$$

Where $S$ and $S_{\mathrm{o}}$ represent the slope and intercept on the obtained solubility diagram, respectively.

Behavior of Allixin Inclusion Compound in BSA Solution and Blood/Serum of Experimental Animal BSA was dissolved in phosphate buffered saline (PBS) solution, and the concentration of BSA was adjusted to $8 \%$. This BSA solution was used as the simulated serum. One gram of allixin inclusion compound was dissolved in purified water, and the mixture volume was made to $5 \mathrm{ml}$ (allixin concentration : $10.4 \mathrm{mg} / \mathrm{ml}$ ). BSA solution was added to $1300 \mu \mathrm{l}$ of allixin inclusion compound solution to make a volume of $10 \mathrm{ml}$. This mixture was incubated at $37^{\circ} \mathrm{C}$ for 5 and $15 \mathrm{~min}$. After incubation, the mixture was immediately filtered with a filter unit, DISMIC25 (pore size: $0.20 \mu \mathrm{m}$, ADVANTEC TOYO, Japan), and the obtained filtrate was placed in a centrifugal filter device, Centriplus YM-10 (cut off: $10^{4}$, Millipore Co., Bedford, U.S.A.). This device was centrifuged at $3000 \boldsymbol{g}$ for $30 \mathrm{~min}$, then the ultrafiltrate and remaining solution were recovered. The filter unit, DISMIC-25, was rinsed with $5 \mathrm{ml}$ of PBS, then allixin trapped with the filter was eluted with $20 \mathrm{ml}$ of $90 \%$ methanol. Five hundred microliters of the ultrafiltrate and remaining solution were placed in a $20 \mathrm{ml}$ volumetric flask, and acetonitrile was added to volume, respectively. These mixtures were sonicated at around $15-20^{\circ} \mathrm{C}$ for $15 \mathrm{~min}$, then a part of these mixtures was centrifuged at $15000 \mathrm{rpm}$ for $10 \mathrm{~min}$. The obtained supernatants and eluate from DISMIC-25 were analyzed by HPLC. The adhesion of allixin in the filter unit, DISMIC-25, was tested in the same manner as described in the above, without BSA solution.

The stability of the inclusion compound in serum was tested using rat serum. Blood was collected from the femoral vein of Wistar rats under ether anesthesia using a plastic heparinized/non-heparinized injector. Non-he- 
parinized blood was kept at room temperature for $30 \mathrm{~min}$, blood was centrifuged at $2000 \boldsymbol{g}$ for $30 \mathrm{~min}$, then the serum phase was used for the stability experiment. The stability test in serum was performed in the same manner as serum stimulated with BSA, as described above.

The stability of allixin in whole blood was tested using rat blood heparinized as described above. Four hundred microliters of allixin inclusion compound solution was mixed with whole blood to attain a volume of $3 \mathrm{ml}$. This mixture was incubated at $37^{\circ} \mathrm{C}$. One hundred microliters of this mixture was sampled at 5, 10, 15, 30 and $60 \mathrm{~min}$ after incubation, and, the mixture sampled was placed in a $10 \mathrm{ml}$ volumetric flask, then acetonitrile was added to attain the full volume. These mixtures were sonicated at $15-20^{\circ} \mathrm{C}$ for $15 \mathrm{~min}$, then part of these mixtures was centrifuged at $15000 \mathrm{rpm}$ for 10 min. The obtained supernatants were analyzed by HPLC. Analytical HPLC conditions were the same as in the preparation of inclusion compound of allixin with M- $\beta$-Cyd and analysis of allixin content in inclusion compound.

Administration of Allixin to Experimental Animal Two grams of allixin inclusion compound was dissolved in $10 \mathrm{ml}$ of purified water at room temperature. Osmo-regulation of the administration solution was controlled to avoid lake on intravenous administration based on analytical results of composition of the inclusion compound, such as the content of allixin, M- $\beta$ Cyd and resulting $\mathrm{NaCl}$ by $\mathrm{NaOH}$ solution and $\mathrm{HCl}$ solution in preparation of the inclusion compound. The prepared inclusion compound solution was administrated to fasted mice $(25-30 \mathrm{~g})$ by an intravenous and peroral route within $2 \mathrm{~h}$ after preparation. The administrated dose for the mice was $50 \mathrm{mg}$ allixin $/ 5 \mathrm{ml} / \mathrm{kg}$.

Collection of Blood Sample and Organs on Administration Experiment Blood samples were collected from cervix blood vessels at one, 5, $10,15,30,60$ and $120 \mathrm{~min}$ after intravenous and oral administration (blood and organ samples were not collected at $1 \mathrm{~min}$ after peroral administration). Collected blood was kept for $30 \mathrm{~min}$ at room temperature, and then centrifuged at about $2000 \boldsymbol{g}$ for $15 \mathrm{~min}$. Serum was collected for the analytical sample and was kept frozen at $-80^{\circ} \mathrm{C}$ until analysis. Mice were sacrificed by decapitation after collection of the blood, then the brain, kidneys, liver and lungs were immediately removed. Each of the isolated organs were weighed and then frozen by liquid nitrogen. Obtained organs were kept frozen at $-80^{\circ} \mathrm{C}$ until analysis.

Preparation of Sample Solution for LC-MS Analysis Serum sample $(50 \mu \mathrm{l})$ was placed into a $1.5 \mathrm{ml}$ sample cup, and about $50 \mathrm{mg}$ of $\mathrm{NaCl}, 20 \mu \mathrm{l}$ of $2 \mathrm{~N} \mathrm{HCl}, 50 \mu \mathrm{l}$ of internal standard solution and $1 \mathrm{ml}$ of acetonitrile were added. The resulting mixture was shaken vigorously using vortex mixer for $1 \mathrm{~min}$, followed by sonication for $20 \mathrm{~min}$ at around $15^{\circ} \mathrm{C}$ to $20^{\circ} \mathrm{C}$. This mixture was centrifuged at $15000 \mathrm{rpm}$ for $5 \mathrm{~min}$, and the obtained supernatant was used as a sample preparation for LC-MS analysis.

Each organ was placed into a glassware homogenizer with acetonitrile in the amount of about ten times the organs weight, $50 \mu \mathrm{l}$ of $2 \mathrm{~N} \mathrm{HCl}$ and $100 \mu 1$ of internal standard solution. This mixture was homogenized. The obtained homogenate was transferred to $15 \mathrm{ml}$ of plastic tube and was sonicated for $60 \mathrm{~min}$ at $20^{\circ} \mathrm{C}$ to $30^{\circ} \mathrm{C}$ for extraction. This mixture was centrifuged at $2000 \mathrm{~g}$ for $15 \mathrm{~min}$, then the supernatant was transferred to $15 \mathrm{ml}$ of plastic tube. The solvent of this solution was removed in vacuo. One milliliter of acetonitrile was added to the resulting residue, shaken vigorously and then sonicated for $20 \mathrm{~min}$ at $20^{\circ} \mathrm{C}$ to $30^{\circ} \mathrm{C}$. The resulting mixture was centrifuged at $15000 \mathrm{rpm}$ for $5 \mathrm{~min}$, then the obtained supernatant was used as a sample preparation for LC-MS analysis.

Quantitative Analysis of Allixin in Serum and Organs by the LC-MS Method LC-MS analysis was performed using an LC-MS system composed of the Hewlett Packard 1100 HPLC system and MS system of Finnigan LCQ. Standard solution and sample solution were separately injected into LC-MS equipment, and chromatograms were recorded in terms of function of the selective ion mode. The calibration curve (regression curve) was prepared using the injected amount of allixin and the peak area ratio of allixin and internal standard, allixin- $d_{11}$. The content of allixin in the sample was calculated by the calibration curve thus obtained based on the peak area ratio of allixin and the internal standard, allixin- $d_{11}$. Analytical conditions were as follows: Mobile phase: mixture of methanol-water-acetic acid (360: 135:5), flow of mobile phase: $0.2 \mathrm{ml} / \mathrm{min}$, column: Cadenza CD-C18 (2 $\mathrm{mm} \phi \times 75 \mathrm{~mm}$, Imtakt, Kyoto, Japan), ionization conditions: APCI, detection: selected ion monitoring of positive ion $\left([\mathrm{M}+\mathrm{H}]^{+}=227\right.$ for allixin, $[\mathrm{M}+\mathrm{H}]^{+}=238$ for internal standard allixin- $\left.d_{11}\right)$. The limit for quantitative analysis on this experiment was $200 \mathrm{ng} / \mathrm{ml}$-serum.

Calculation of Pharmacokinetic Parameters The values of $C_{\max }$ and $T_{\max }$ were determined directly from the obtained allixin concentration-time profile in serum. The values for area under the concentration-time curve $(A U C)$ were calculated by the trapezoidal method. Apparent half-lives were estimated using computer programs for nonlinear regression analysis.

Treatment of Allixin with S-9 Mix and Preparation of Test Solution for Analysis of Allixin Metabolism Fifty milligrams of allixin was placed into a $100 \mathrm{ml}$ of flask, and $50 \mathrm{ml}$ of PBS solution was added. This mixture was sonicated for about $1 \mathrm{~h}$, and the resulting mixture was filtered by a membrane filter (pore size: $0.45 \mu \mathrm{m}$ ). One milliliter of enzyme fraction and $9 \mathrm{ml}$ of co-factor solution were mixed (S-9/co-factor A set for Ames test was used), then $0.5 \mathrm{ml}$ of this enzyme mixture was placed into a $10 \mathrm{ml}$ glassware tube, and $0.5 \mathrm{ml}$ of PBS solution of allixin (allixin concentration: $158 \mu \mathrm{g} / \mathrm{ml}$ ) was added. Glass tubes containing the resulting mixture were incubated at $37^{\circ} \mathrm{C}$ for $5,10,15,30$ and $60 \mathrm{~min}$. Methanol was immediately added to each of the incubated tubes after each incubation time, and these mixtures were brought to $5 \mathrm{ml}$ volume with methanol. The resulting mixtures were vigorously shaken for $10 \mathrm{~min}$, then centrifuged for another $10 \mathrm{~min}$ at about 2000 g. The obtained supernatant was used as a sample preparation for the analysis of allixin metabolism. Analytical HPLC conditions were the same as in the preparation of inclusion compound of allixin with M- $\beta$-Cyd and analysis of allixin content in inclusion compound.

Treatment of Allixin with Liver Homogenate and Preparation of Test Solution for Analysis of Allixin Metabolism Fourteen-week-old male Wistar rats were sacrificed by decapitation, and their livers were immediately removed. These livers were washed with PBS solution and $10 \%(\mathrm{w} / \mathrm{v})$ of liver homogenate was prepared using PBS solution. Two milliliter of this liver homogenate was placed into a $10 \mathrm{ml}$ glassware tube, and $1 \mathrm{ml}$ of PBS solution of allixin (allixin concentration: $107.4 \mu \mathrm{g} / \mathrm{ml}$ ) was added. Glass tubes containing the resulting mixture were incubated at $37^{\circ} \mathrm{C}$ for $5,10,20$ and $60 \mathrm{~min}$. Five milliliters of acetonitrile, $0.5 \mathrm{~g}$ of $\mathrm{NaCl}$ and $50 \mu \mathrm{l}$ of $2 \mathrm{~N}$ $\mathrm{HCl}$ was immediately added each of the incubated tubes after incubation. The resulting mixtures were vigorously shaken for $10 \mathrm{~min}$ and centrifuged for another $10 \mathrm{~min}$ at about $2000 \mathrm{~g}$. The supernatant was placed into a $10 \mathrm{ml}$ volumetric flask, and acetonitrile was added to attain full volume. A part of this solution was centrifuged at $15000 \mathrm{rpm}$ for $5 \mathrm{~min}$, and the obtained supernatant was used as a sample preparation for analysis. Analytical HPLC conditions were the same as in the preparation of inclusion compound of allixin with M- $\beta$-Cyd and analysis of allixin content in inclusion compound.

Recovery of Allixin Metabolites on S-9 Mix Treatment Fifteen milliliters of PBS was added to about $50 \mathrm{mg}$ of allixin, and this mixture sonicated for $20 \mathrm{~min}$ to dissolve the allixin. Five milliliters of S-9 Mix and $45 \mathrm{ml}$ of cofactor was mixed, and the resulting mixture was added to allixin suspended in PBS mixture. This mixture was incubated at $37{ }^{\circ} \mathrm{C}$ for $3 \mathrm{~h}$. Three hundred milliliters of methanol was added to the treatment mixture after incubation, and then this mixture was shaken, vigorously. This mixture was centrifuged at about $2000 \mathrm{~g}$ for $10 \mathrm{~min}$, then the supernatant was recovered as a metabolite-containing fraction. This fraction was concentrated in vacuo, and $50 \mathrm{ml}$ of methanol was added to the residue. This extraction and concentration process was repeated three times. The resulting concentrated fraction was dissolved in $50 \mathrm{ml}$ of acetonitrile, and this mixture was centrifuged at about $2000 \boldsymbol{g}$ for $10 \mathrm{~min}$. The supernatant was recovered and then the solvent was removed in vacuo. The obtained residue was used for the further separation and purification of allixin metabolites.

It was observed that the recovered fraction, the metabolite-containing mixture, contained a considerable amount of non-metabolized allixin. The retention times of several new peaks as metabolites were very different from retention time of allixin with each metabolite (refer Fig. 8). Therefore, as a first separation step, the recovered mixture was separated into 2 fractions, the metabolite-containing fraction and the unchanged allixin-containing fraction, by the following conditions: column: TSK gel ODS 80TM ( guard for preparative column, $21.5 \mathrm{~mm} \phi \times 75 \mathrm{~mm}$ ), solvent: mixture of methanol and water (54:46), detection: UV $280 \mathrm{~nm}$ absorption, flow: $5 \mathrm{ml} / \mathrm{min}$.

The recovered allixin metabolite-containing fraction was concentrated in vacuo and the resulting mixture was purified on a second separation step by the following conditions: TSK gel ODS $80 \mathrm{TM}(4.6 \mathrm{~mm} \phi \times 150 \mathrm{~mm})$, solvent: mixture of methanol and water $(54: 46)$, detection: UV $280 \mathrm{~nm}$ absorption, flow: $0.6 \mathrm{ml} / \mathrm{min}$. Each obtained fraction containing allixin metabolite was concentrated in vacuo, and the resulting residue was dried under reduced pressure with phosphorus pentoxide.

Analysis of Allixin Metabolites Using the HPLC Method Prepared test solutions containing metabolites of allixin on treatment with S-9 Mix were dried in vacuo after analysis of allixin metabolism. The resulting residue was suspended in $0.5 \mathrm{ml}$ of methanol, and this mixture was centrifuged at $15000 \mathrm{rpm}$ for $5 \mathrm{~min}$, then the obtained supernatant was used as a sample solution. Here, the used sample volume for analysis of metabolized allixin was not considered for this analysis because the used sample volume was less than $2 \%$ of the initial concentration. For a general quantitative 
analysis of allixin metabolites, 3-hydroxy-2,6-dimethyl-4H-pyran-4-one was used as the standard. However, this was not accurate quantitative analysis because it is difficult to synthesize each of the allixin metabolites. The obtained sample solution was analyzed under the following conditions: column: TSK gel ODS $80 \mathrm{TM}(4.6 \mathrm{~mm} \phi \times 150 \mathrm{~mm})$, solvent: gradient with mixture of water and methanol $(60: 40)$ and mixture of methanol and water $(90$ : 10), detection: UV $280 \mathrm{~nm}$, flow: $0.6 \mathrm{ml} / \mathrm{min}$.

LC-MS Analysis of Allixin Metabolites The LC-MS analysis was performed using an LC-MS system composed of a Hewlett Packard 1100 HPLC system and MS system of Finnigan LCQ. Analytical conditions were as follows: mobile phase: mixture of water-methanol $(600: 400)$, flow of mobile phase: $0.6 \mathrm{ml} / \mathrm{min}$, column: TSK gel ODS $80 \mathrm{TM}(4.6 \mathrm{~mm} \phi \times 150$ $\mathrm{mm}$, Tosoh, Japan). Ionization conditions: APCI, detection: positive ion.

NMR Analysis of Metabolites Each metabolite fraction obtained was dried in vacuo under existing phosphorus pentoxide. The resulting dried residue was dissolved in deuterium oxide, then NMR analysis was performed at ${ }^{1} \mathrm{H}-\mathrm{NMR}$ and ${ }^{1} \mathrm{H}-{ }^{1} \mathrm{H}$ COSY NMR mode.

Acknowledgement We greatly thank Ms. Brenda Lynn Petesch, M.S., Nutritionist, Supervisor, Research and Development, Wakunaga of America Co., Ltd., for suggesting for our present study.

\section{References}

1) Koch H. P., Lawson L. D. (eds.), "Garlic, The Science and Therapeutic Application of Allium sativum L. and Related Species," Williams and Wilkins, Baltimore, Maryland, U.S.A., 1996.

2) Saitoh H., (ed.), "Garlic Science" (Ninniku no kagaku, in Japanese), Asakura Syoten, Tokyo, Japan, 2000.

3) Nagae S., Ushijima M., Hatono S., Imai J., Kasuga S., H. Matsuura, Itakura Y., Higashi Y., Planta Med., 60, 214-217 (1994).

4) Lachance P. A. (ed.), "Nutraceuticals: Designer Foods III Garlic, Soy and Licorice," Chapter 11, Food \& Nutrition Press, Inc., Trumbull, CT, U.S.A., 1997.

5) Hatono S., Jmenez A., Wargovich M. J., Carcinogenesis, 17, 10411044 (1996).

6) Ide N., Lau B. H. S., Drug Dev. Ind. Pharm., 25, 619-624 (1999).

7) Matsuura H., J. Nutr., 131, 1000S-1005S (2001).

8) Itakura Y., Ichikawa M., Mori Y., Udayama M., Morita T., J. Nutr., 131, 963S-967S (2001).

9) Hirao Y., Sumioka S., Yamamoto M., Hatono S., Yoshida S., Fuwa T., Nakagawa S., Phytother. Res., 1, 161-164 (1987).

10) Ryu K., Ide N., Matsuura H., Itakura Y., J. Nutr., 131, 972S—976S (2001).
11) Kodera Y., Matuura H., Yoshida S., Sumida T., Itakura Y., Fuwa T., Nishino H., Chem. Pharm. Bull., 37, 1656-1658 (1989).

12) Nishino H., Nishino A., Takayama J., Iwashima A., Itakura Y., Kodera Y., Matsuura H., Fuwa T., Cancer J., 3, 20-21 (1990).

13) Yamasaki T., Teel R. W., Lau B. H. S., Cancer Lett., 59, 89-94 (1991).

14) Moriguchi T., Matsuura H., Itakura Y., Katsuki H., Saito H., Nishiyama N., Life Sci., 61, 1413-1420 (1997).

15) Nishino H., Kodera Y., Sumida T., Matsuur H., Yoshida S., Itakura., US Patent US5093505.

16) Matsumura Y., Shirai K., Maki T., Itakura Y., Kodera Y., Tetrahedron Lett., 39, 2339-2340 (1998)

17) Ikeda K., Uekama K., Yakkyoku 23, 1165-1170 (1972).

18) Bailey J. A., Mansfield J. W., "Phytoalexins," John Wiley and Sons, New York Toronto, 1982.

19) Grayer R. J., Kokubun T., Phytochemistry, 56, 253-263 (2001).

20) Ikeda K., Uekama K., Otagiri M., Chem. Pharm. Bull., 23, 201-208 (1975).

21) Uekama K., Hirayama F., Irie T., Chem. Rev., 98, 2045-2076 (1998).

22) Becket G., Schep L. J., Tan M. Y., Int. J. Pharmaceut., 179, 65-71 (1999).

23) Kanda Y., Yamamoto Y., Inoue Y., Chujo R., Kobayashi S., Bull. Chem. Soc. Jpn., 62, 2002-2008 (1989).

24) Tokihiro K., Irie T., Uekama K., Chem. Pharm. Bull., 45, 525-531 (1997).

25) Ikeda K., Uekama K., Yakkyoku, 24, 53-59 (1973).

26) Guo Z., Miller D., Pentz R., Kress G., Siegers C. P., Planta Med., 56, 692 (1990).

27) Kontoghiorghes G. J., Aldouri M. A., Sheppard L., Hoffbrand A. V., Lancet, 1987, 1294-1295.

28) Singh S., Epemolu R. O., Dobbin P. S., Tilbrook G. S., Ellis B. L., Damani L. A., Hider R. C., Drug Metabolism and Disposition, 20, 256-261 (1992).

29) Barrand M. A., Callingham B. A., Hider R. C., J. Pharm. Pharmacol., 39, 203-211 (1987).

30) Yokel R. A., Fredenburg A. M., Durbin P. W., Xu J., Rayens M. K., Raymond K. N., J. Pharm. Sci., 89, 545-555 (2000).

31) Liu Z. D., Liu D. Y., Lu S. L., Hider R. C., J. Pharm. Pharmacol., 51, 555-564 (1999).

32) Molenda J. J., Ones J M. K., Jonson D. J., Walker E. M., Jr., Cannon D. J., J. Med. Chem., 37, 4363-4370 (1994).

33) Kohlert C., van Rensen I., Marz R., Schindler G., Graefe E. U., Veit M., Planta Med., 66, 495-505 (2000). 